\title{
Alternative strategies for amphibian conservation: a response to Muths \& Fisher
}

\author{
FRANCO ANDREONE
}

$\mathrm{T}$ he so-called amphibian crisis is mostly managed by IUCN through the Species Survival Commission Amphibian Specialist Group in collaboration with the Amphibian Survival Alliance, and its management is considered to be the most important implementation of the Amphibian Conservation Action Plan (Gascon et al., 2007). In the Amphibian Conservation Action Plan meeting held in 2005 several actions were planned and the investment needed for amphibian conservation was estimated. More than a decade later, however, much remains to be done, especially in response to heterogeneous emergencies that could cause amphibian extinctions. In this context Muths \& Fisher (2015) suggest an alternative approach.

The title of their article is, however, potentially misleading, implying a global perspective and an international response to the crisis. Rather, the focus is limited to the appearance and spread of, and responses to the threats caused by, two amphibian pathogenic chytrid fungi: Batrachochytrium dendrobatidis (Bd) and Batrachochytrium salamandrivorans (Bsal). In particular, Muths \& Fisher emphasize the risks to the highly diverse North American urodele fauna of the potential introduction and spread of Bsal (Yap et al., 2015). This chytrid was described recently from the Netherlands and subsequently found elsewhere in Europe, where it has caused local salamander extinctions (Martel et al., 2013). Urodeles imported into North America from Asia through the international pet trade are considered the main potential vectors of Bsal. There has been intense discussion, especially in the USA, about whether and how the salamander and wider amphibian trade can be controlled to prevent introduction of the pathogen. For Bd the exotic pet trade is considered just one of the possible infection pathways but for Bsal this trade is considered a major pathway, thus providing a political and conservation justification for limiting the exotic pet trade (Stokstad, 2014).

Muths \& Fisher discuss the possibility of changing the approach to the amphibian crisis, proposing the application of an Incident Command System to prevent Bsal entering the USA. This proposal is interesting, but limited. Firstly, because this proposal is restricted to Bsal (which is just part of the overall problem) and, secondly, because it is

Franco Andreone Museo Regionale di Scienze Naturali Via G. Giolitti, 36, I-10123 Torino, Italy. E-mail franco.andreone@regione.piemonte.it

Received 22 June 2016. Accepted 23 June 2016. First published online 16 November 2016.
USA-centric. An Incident Command System approach could only be part of the multiple responses required to address the global amphibian crisis, and its implementation would mostly be local.

Moreover, although the amphibian decline is a global crisis and should therefore be of concern to everybody, the crisis does not directly affect people, except for a few cases associated with exploitation of frogs for food and for income generated from traditional medicine and the pet trade. Thus, although we are discussing the potential extinction of a whole vertebrate class, the level of human interest is limited and does not seem sufficiently high to warrant the implementation of an Incident Command System. Such systems are generally developed by local task forces and emergency services when there is an immediate risk to people, such as in the case of earthquakes, floods, tsunamis and epidemics (Bigley \& Roberts, 2001).

If we wish to have a global approach to the amphibian crisis a further difficulty is how to manage the situation in developing tropical countries. In Madagascar, where I have experience developing conservation plans (Andreone et al., 2016), there are two major threats to amphibians. The first is the discovery of $\mathrm{Bd}$ in several locations, some of which are home to species in danger of immediate extinction (Bletz et al., 2015). This finding was the result of the implementation of a national monitoring programme. The second is the recent introduction of the invasive Asian toad Duttaphrynus melanostictus (Crottini et al., 2014), which poses a serious threat to a fauna that includes $>300$ endemic frog species. The cost of control or eradication of a non-indigenous species is so high that it is difficult to justify in a country where economic conditions are hard.

In the case of the trade in frog legs in Europe and elsewhere (Carpenter et al., 2014), control by CITES can help prevent the extinction of species affected by unsustainable offtake for export. This is possible when the trade occurs in traditional ways, with a chain of collectors, exporters and dealers. In other cases the trade is largely hidden and therefore difficult to control. This is, for example, one of the major problems with respect to trade of Balkan green frogs of the genus Pelophylax and their importation into several western European countries (Holsbeek et al., 2008). Vorburger \& Reyer (2003) showed that P. kurtmuelleri is replacing the native $P$. esculentus and $P$. lessonae in many areas of western Europe by genetic pollution, with expulsion of the lessonae genome. This genetic pollution is 
mostly unappreciated because the Balkan frogs are perceived by citizens to be simply green frogs and are therefore rarely considered a threat to local and autochthonous frog populations. Balkan frogs are often imported by road from Romania, Turkey and Greece, without passing any custom or sanitary control. They are traded live, and when they reach their destination (mostly local markets) they easily escape or may be released by well-meaning citizens. Once in the wild they interbreed with autochthonous species and eliminate them in a sort of amphibian genocide. Large areas of France and north-west Italy have almost lost their original green frog fauna, which has been replaced by several of these allochthonous species (Domeneghetti et al., 2013).

For such cases an Incident Command System would be welcome but unrealistic to implement. Such a system would be practical only in some well-defined cases. Most likely the situation discussed by Muths \& Fisher is one of these rare cases where this could be applied. The USA already uses such strategies and there is a tradition of strong lobbying by conservation leaders, who could potentially convince politicians that control of the pet trade is essential to prevent the catastrophe that would result from the spread of an emerging pathogen such as Bsal. In this country and in this case, at least, the implementation of an Incident Command System may be feasible. Elsewhere, other methods and strategies need to be identified and implemented.

\section{References}

Andreone, F., Dawson, J., Rabemananjara, F.C.E., Rabibisoa, N. H.C. \& Rakotonanahary, T. (eds) (2016) New Sahonagasy Action Plan 2016-2020. Museo Regionale di Scienze Naturali and Amphibian Survival Alliance, Turin, Italy.

Bigley, G.A. \& Roberts, K.H. (2001) The Incident Command System: high-reliability organizing for complex and volatile task environments. Academy of Management Journal, 6, 1281-1299.

Bletz, M.C., Rosa, G.M., Andreone, F., Courtois, E.A., Schmeller, D.S., Rabibisoa, N.H.C. et al. (2015) Widespread presence of the pathogenic fungus Batrachochytrium dendrobatidis in wild amphibian communities in Madagascar. Scientific Reports, 5, $1-10$.

Carpenter, A.I., Andreone, F., Moore, R.D. \& Griffiths, R.A. (2014) A review of the international trade in amphibians: the types, levels and dynamics of trade in CITES-listed species. Oryx, 48, 565-574.
Crottini, A., Andreone, F., Edmonds, D., Hansen, C.M., Lewis, J. P., RabemanantsoA, J.C. et al. (2014) A new challenge for amphibian conservation in Madagascar: the invasion of Duttaphrynus melanostictus in Toamasina province. FrogLog, 111, 46-47.

Domeneghetti, D., Bruni, G., Fasola, M. \& Bellati, A. (2013) Discovery of alien water frogs (gen. Pelophylax) in Umbria, with first report of P. shqipericus for Italy. Acta Herpetologica, 8, $171-176$.

Gascon, C., Collins, J.P., Moore, R.D., Church, D.R., Mc Kay, J. E. \& Mendelson, III, J.R. (eds) (2007) Amphibian Conservation Action Plan. IUCN/SSC Amphibian Specialist Group, Gland, Switzerland.

Holsbeek, G., Mergeay, J., Hotz, H., Plötner, J., Volckaert, F. A.M. \& De Meester, L. (2008) A cryptic invasion within an invasion and widespread introgression in the European water frog complex: consequences of uncontrolled commercial trade and weak international legislation. Molecular Ecology, 17, 5023-5035.

Martel, A., Spitzen-van der Sluijs, A., Blooi, M., Bert, W., Ducatelle, R., Fisher, M.C. et al. (2013) Batrachochytrium salamandrivorans sp. nov. causes lethal chytridiomicosis in amphibians. Proceedings of the National Academy of Sciences of the United States of America, 110, 15325-15329.

Muths, E. \& Fisher, R.N. (2015) An alternative framework for responding to the amphibian crisis. Oryx, http://dx.doi.org/10.1017/ So030605315001131.

Peel, A.J., Hartley, M. \& Cunningham, A.A. (2012) Qualitative risk analysis of introducing Batrachochytrium dendrobatidis to the UK through the importation of live amphibians. Diseases of Aquatic Organisms, 98, 2, 95-112.

Stokstad, E. (2014) The coming salamander plague. Science, 346, 530-531.

Vorburger, C. \& Reyer, H.U. (2003) A genetic mechanism of species replacement in European waterfrogs? Conservation Genetics, 4, 141-155.

Yap, T.A., Koo, M.S., Ambrose, R.F., Wake, D.B. \& Vredenburg, V.T. (2015) Averting a North American biodiversity crisis. Science, 349, 481-482.

\section{Biographical sketch}

FrANCO ANDREONE has studied amphibians for more than 30 years, devoting particular attention to the interface between taxonomy, ecology and conservation biology. He is co-chair of the IUCN Amphibian Specialist Group in Madagascar, where he conducts research and coordinates the implementation of the national action plan for amphibian conservation. 